\title{
THE APPLICATION OF THE FINITE ELEMENT METHOD FOR STATIC BEHAVIOUR ANALYSIS OF THE ASYMMETRICAL ONE-PYLON SUSPENSION BRIDGE BUILT-IN BENDING CABLES OF DIFFERENT RIGIDITY
}

\author{
Tatjana GRIGORJEVA ${ }^{1^{*}}$, Ainars PAEGLITIS ${ }^{2}$ \\ ${ }^{1}$ Vilnius Gediminas Technical University, Sauletekio al. 11, LT-10223 Vilnius, Lithuania \\ ${ }^{2}$ Rigas Technical University, Kalku str. 1, LV-1658, Riga, Latvia
}

Received 3 April 2018; accepted 17 October 2018

\begin{abstract}
The article presents the results of the numerical analysis of the asymmetrical one-pylon suspension bridge builtin rigid cables. The models for the suspension bridge with the cables of different rigidity are analyzed by comparing vertical displacements, bending moments and strains in the structural members of the bridge. The numerical analysis was performed by examining the bridge under symmetrical and asymmetrical loading and different erection methods. The stress-strain state of a single asymmetrical pylon with the cables of different rigidity and the rational relationship between cable rigidity and girder stiffness has been established.
\end{abstract}

Keywords: suspension bridges, rigid cables, FE modelling, displacements, moments and stresses, bridge erection.

\section{Introduction}

The structures of suspended bridges are effective from the technical and economic points of view and have an expressive architectural form (Gimsing \& Georgakis, 2012; Troyano, 2003; Ryall, Parke, \& Harding, 2000; Bennet, 1997). The increased strain, particularly under the action of asymmetrical loading, is the main drawback of such bridges (Kiisa, Idnurm, \& Idnurm, 2012; Kulbach, 2007; Juozapaitis \& Norkus, 2007). Thus, to reduce the occurring kinematic displacements, a sufficient variety of structural measures have been proposed (Jennings, 1987; Strasky, 2005). A large number of analytical methods for calculating classical suspension bridges with rigid cables are based on nonlinear calculations according to the distorted scheme (Arco \& Aparicio, 2001; Clemente, Nicolosi, \& Raithel, 2000; Gimsing \& Georgakis, 2012; Idnurm, 2006; Jennings, 1987; Kim \& Thai, 2010; Kulbach, 2007; Wollmann, 2001). Also, plenty of studies on the dynamic characteristics of suspension bridges have been carried out (Capsoni, Ardito, \& Guerrieri, 2017; Goremkins, Rocens, Serdjuks, \& Sliseris, 2013; El Ouni \& Kahla, 2012; Sousa, R., Souza, R. M., Figueiredo, \& Menezes, 2011; Treyssede, 2010).

The employment of rigid cables is one of the most effective ways to make a suspension bridge stiff enough (Grigorjeva, Juozapaitis, \& Kamaitis, 2010a; Juozapaitis,
Idnurm, S., Kaklauskas, Idnurm, J., \& Gribniak, 2010; Juozapaitis, Kliukas, Sandovič, Lukoševičienè, \& Merkevičius, 2013). Variations in the ratio of cable rigidity to girder stiffening may result in a reduction of the vertical displacements of the bridge and assist in providing rigidity for the complete structure. The simplified calculation methodology for the classical symmetrical one-span bridge with rigid cables is given in the previous publications prepared by the authors of this article (Grigorjeva et al., 2010a). The paper by (Grigorjeva \& Juozapaitis, 2013) focuses on the revised methodology for symmetrical one-span suspension bridges with rigid cables. Moreover, the authors have performed numerical experiments on classical symmetrical suspension bridges with rigid cables (Grigorjeva, Juozapaitis, Kamaitis, \& Paeglitis, 2008).

Several methods can be used for erecting suspension bridges with rigid cables (Grigorjeva, Juozapaitis, \& Kamaitis, 2010b). The first one embraces mounted pylons, and the applied cable has finite bending rigidity. Next, hangers and a stiffening girder are installed. Under such method for bridge erection, a rigid cable takes over all permanent and short-term loading. As for the $2^{\text {nd }}$ method for the construction and erection of the suspension bridge with finite bending rigidity cables, a rigid cable is assem-

*Corresponding author. E-mail: tatjana.grigorjeva@vgtu.lt 
bled from separate flexibly connected members, and hangers and the stiffening girder are installed. At this stage, the cable is exposed to symmetrical permanent loading, and its behaviour corresponds to that of the totally flexible cable. Before loading the bridge with a short-term load, the interconnection nodes of the individual members of the cable are 'stiffened'. The methodology for calculating the classical suspension bridge considering the installation stages of suspension bridges with rigid cables were proposed in the previous publications by the authors of the article, i.e. (Grigorjeva et al., 2010b).

In order to investigate the behaviour of the asymmetrical one-pylon suspension bridge with rigid cables, an analytical calculation methodology must be prepared and numerical experiments must be performed. For conducting numerical analysis evaluating the above discussed erection techniques, the application of specific software for bridge calculations and analysis is only possible, and MI$D A S / C i v i l$ is one of those. The peculiarities of modelling suspension bridges with rigid cables in the environment of MIDAS/Civil software were discussed by (Grigorjeva \& Juozapaitis, 2013). At the beginning of the numerical experiment, the application of procedures defined by $M I-$ $D A S / C i v i l$ software and used for calculating suspension bridges assists with determining the initial stress-strain state of the bridge taking into account the effect of permanent loading $g$. Then, the internal forces of the members of the bridge, under the effect of permanent loading, are attributed to the members of the bridge using certain functions. The bridge is loaded with short-term loading, and the final stress-strain state of the bridge is determined.

This paper presents the findings of the numerical analysis of the asymmetrical one-pylon suspension bridge with rigid cables considering two types of installation.

\section{Description of the FE model}

The numerical analysis of the asymmetrical one-pylon suspension bridge was carried out using specific bridge computing and analysis software MIDAS/Civil. The spatial model for the investigated bridge is presented in Figure 1. The conducted numerical analysis is based on the following assumptions:

- only static loading have an effect on the structure of the bridge;

- the behaviour of the structure is elastic;

- static loading is evenly distributed over the stiffening girder through the entire span of the bridge;

- static loading across hangers is evenly transmitted to the rigid cable;

- hangers are not extended.

The rigid cable is exposed to permanent symmetrical loading $g$ and a part of short-term symmetrical loading $p_{c}$. The stiffening girder holds a part of short-term symmetrical loading $p_{g}$. The main span of the bridge is equal to $l=50 \mathrm{~m}$, the initial sag in the middle of the span of the cable is equal to $f=5.0 \mathrm{~m}$ and the distance between hangers makes $2.5 \mathrm{~m}$ (Figure 2). The ratios of cable rigidity to girder stiffness and their relationships are given in Table 1.

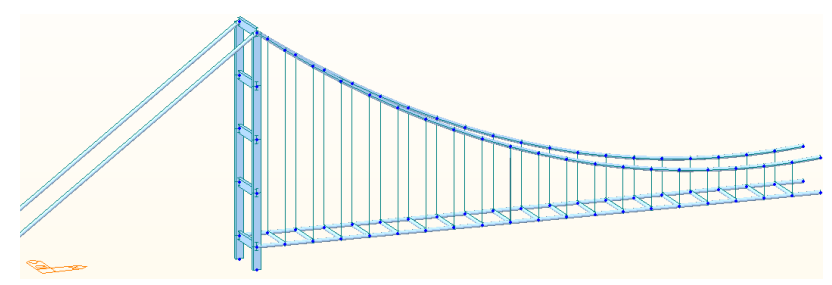

Figure 1. Finite element space model of the bridge
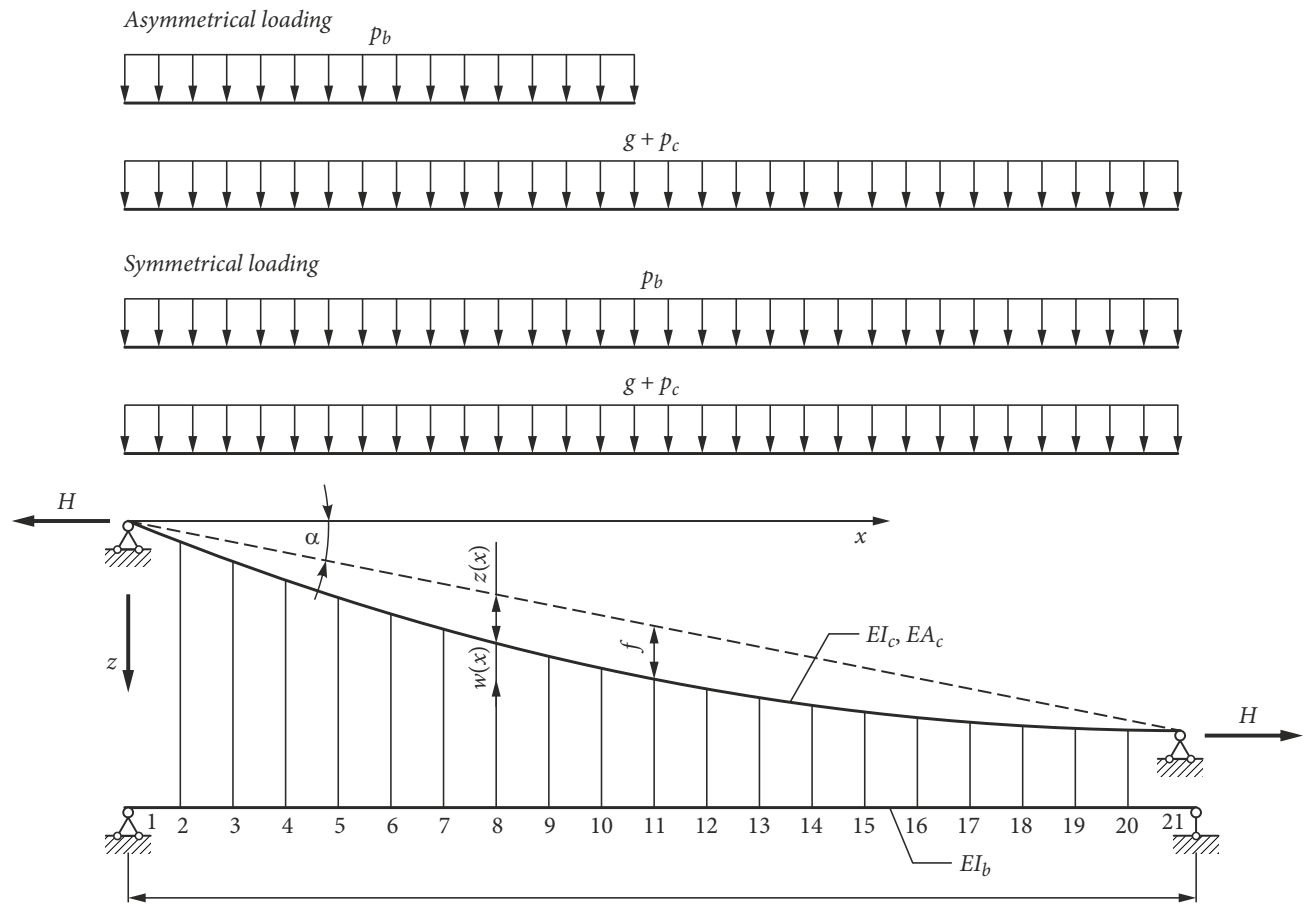

Figure 2. Structural system for a bridge model and loading configuration 
Table 1. Geometric characteristics of the cable and stiffening girder

\begin{tabular}{|c|c|c|c|c|}
\hline$\xi=E I_{c} / E I_{g}$ & $\begin{array}{c}\text { Cable section } \\
d \times t, \mathrm{~mm}\end{array}$ & $\begin{array}{c}\text { Cable rigidity } \\
E I_{c}, \mathrm{kNm}^{2}\end{array}$ & $\begin{array}{c}\text { Stiffening girder section } \\
d \times t, \mathrm{~mm}\end{array}$ & $\begin{array}{c}\text { Stiffening girder rigidity } \\
E I_{g}, \mathrm{kN} / \mathrm{m}^{2}\end{array}$ \\
\hline 0.1 & $150 \times 25$ & 4188 & $350 \times 25$ & 71190 \\
0.5 & $240 \times 25$ & 20770 & $295 \times 25$ & 40930 \\
1.0 & $280 \times 25$ & 34510 & $280 \times 25$ & 34510 \\
2.0 & $315 \times 25$ & 50660 & $255 \times 25$ & 25380 \\
5.0 & $350 \times 25$ & 71190 & $215 \times 25$ & 14390 \\
\hline
\end{tabular}

The stiffening girder is loaded with evenly distributed constant loading $g$ and short-term loading $p$ that is assumed to be constant and makes $5 \mathrm{kN} / \mathrm{m}^{2}$, whereas permanent loading $g$ is variable and equal to 5,25 and $166 \mathrm{kN} / \mathrm{m}^{2}$ respectively. Correspondingly, the ratio of short-term to permanent loading is $\gamma=1,2$ and 3 .

\section{Structural behaviour under the action of symmetrical loading}

The models for the suspension bridge with the cables of different stiffness are considered by comparing vertical displacements, bending moments and maximum displacements at the $1^{\text {st }}$ and $2^{\text {nd }}$ stages of erection.

Figure 3 and 4 show variations in displacements, maximum deflection, bending moments and strains in the structural members subject to the ratio of cable rigidity to girder stiffness.

The carried analysis showed that both vertical displacements and bending moments and strains in the stiffening girder decrease under the effect of short-term loading. This drop is subject to the ratio of the main cable to girder stiffness. An increase in the ratio of cable rigidity to girder stiffness $\xi$ from 0.1 to 5.0 reduces the displace- ment of the mid-range span by $62 \%$. The maximum bending moment decreases by $86 \%$ in the stiffening girder and increases by $80 \%$ in the stiff cable. Stress in the stiffening girder decreases by $70 \%$. The total stress of the rigid cable is reduced by $62 \%$.

As for the $2^{\text {nd }}$ method for bridge erection, under the ratio of short-term to permanent loading equal to $\gamma=1$, the maximum bending moment and strain of both the rigid cable and stiffening girder are approximately by $50 \%$ lower than those in the $1^{\text {st }}$ method for bridge erection.

Figure 5 shows a distorted diagram of the asymmetrical one-pylon suspension bridge under the effect of symmetrical loading.

\section{Structural behaviour under the action of Asymmetrical Loading}

Figure 6 shows the displacements of the stiffening girder under the effect of asymmetrical loading at the $2^{\text {nd }}$ stage of erection. Under the action of asymmetrical loading, the stiffening girder gains an S-shaped bend that dramatically worsens the performance of the bridge. Figure 7 suggests the maximum values of the displacements of the loaded (left) and unloaded (right) sides of the stiffening girder.
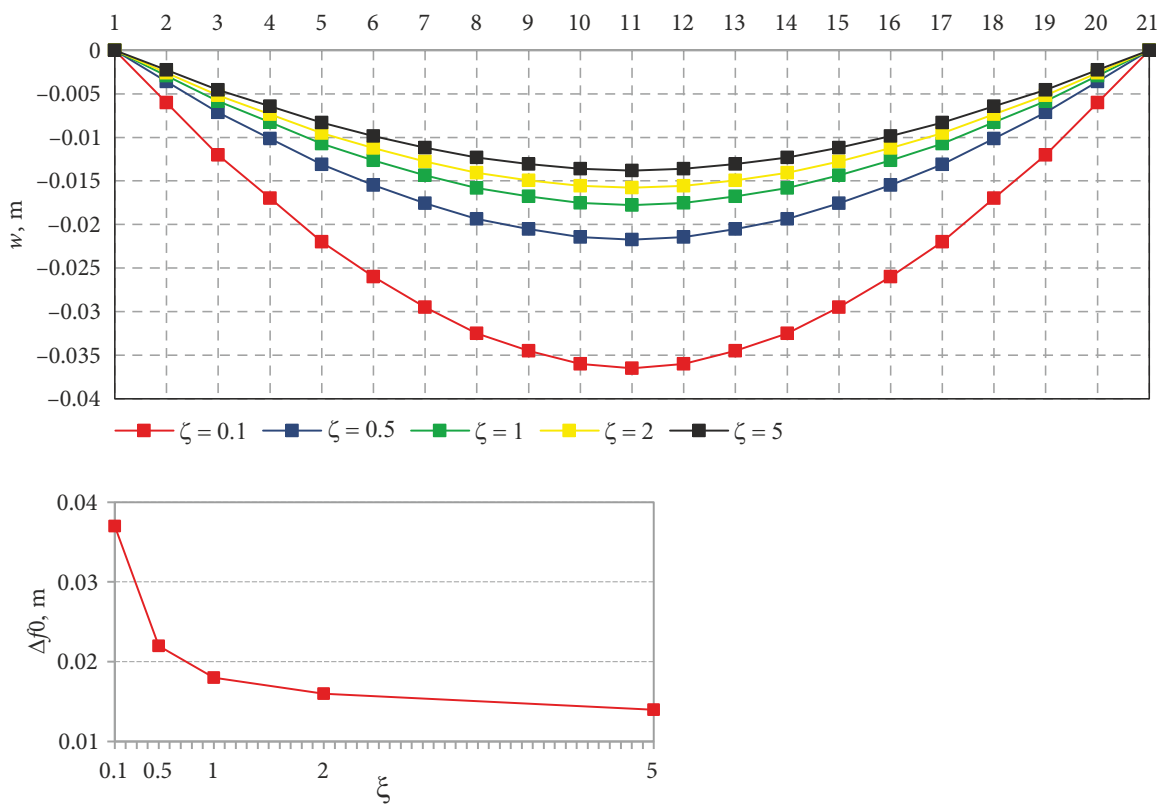

Figure 3. Vertical displacement curves (top) and middle span deflection (bottom) of the stiffening girder under the action of symmetrical loading $(\gamma=1)$ 

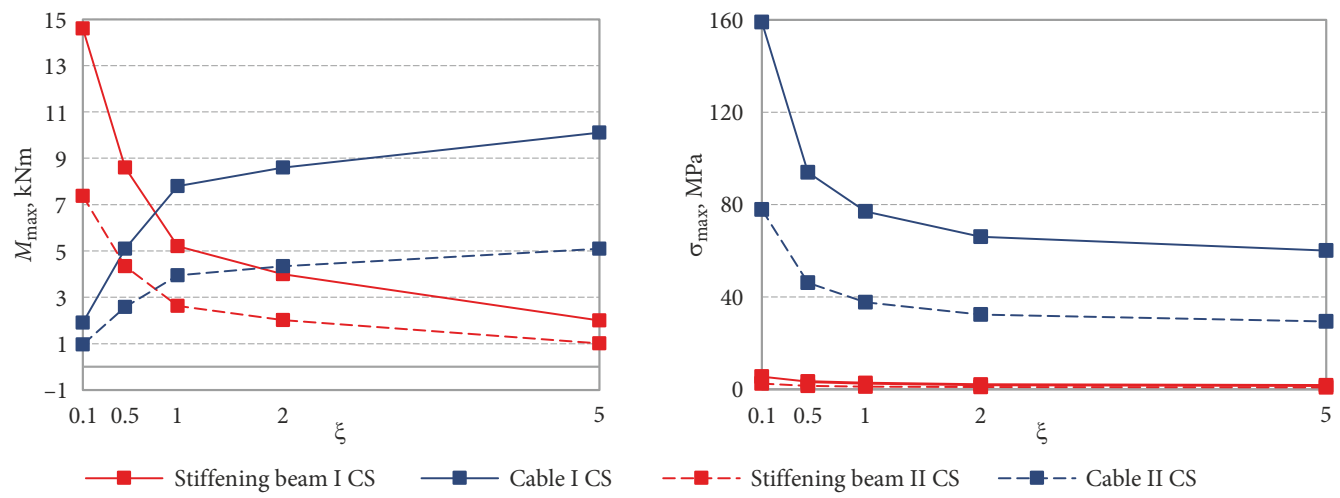

Figure 4. Maximum bending moments (left) and stresses (right) in the middle of the span of the stiffening girder and the cable under the action of symmetrical loading $(\gamma=1)$

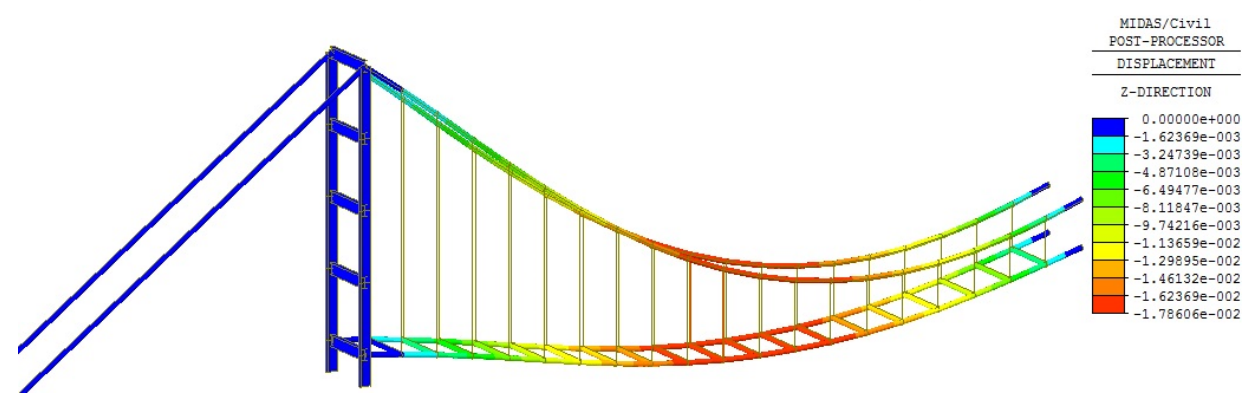

Figure 5. A deformed finite element model for the bridge under symmetrical loading $(\xi=1,0, \gamma=1)$

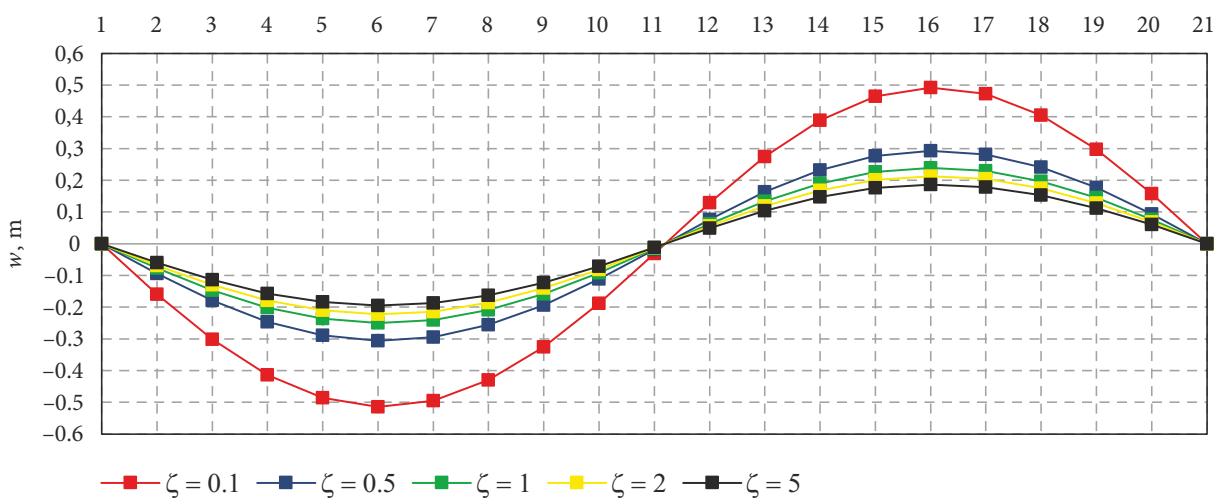

Figure 6. Vertical displacement curves of the stiffening girder under the action of asymmetrical loading $(\gamma=1)$

The maximum displacement is observed in the structure of the bridge the ratio of cable rigidity to girder stiffness of which is the lowest $(\xi=0.1)$.

A rise in the stiffness ratio ends in the reduction of the displacements both the loaded and unloaded part, and therefore the overall stiffness of the bridge increases. The carried out analysis of the displacements of the largest quarter span positions has shown that the most effective construction of the bridge is observed when the ratio of cable rigidity to girder stiffness makes $\xi=1.0-2.0$. Under ratio $\zeta=2.0$, the maximum displacements of quarter span positions are reduced to approximately $50 \%$. An increase in the ratio of cable rigidity to girder stiffness up to 5.0 has no significant effect on the displacements of the girder.

Cable rigidity also affects the distribution of bending moments and strains both in the cable and stiffening girder. Figure 8 shows the charts of the rigid cable of the

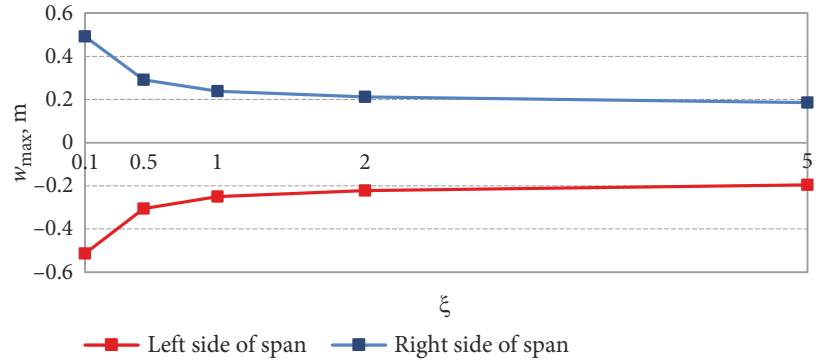

Figure 7. Vertical displacement curves (top) and middle span deflection (bottom) of the stiffening girder under the action of asymmetrical loading $(\gamma=1)$

one-pylon asymmetrical suspension bridge and the bending moments of the girder in the case of the $2^{\text {nd }}$ method for bridge erection under different relationships between short-term and permanent loading $\gamma$. 
By increasing the ratio $\zeta$ of the flexural rigidity of the cable and girder from 0.1 to 5.0 , the maximum bending moment of the stiffening girder decreases by $77 \%, 79 \%$ and $81 \%$ under the ratio of short-term to permanent loading $\gamma=1,2$ and 3 respectively.

By increasing the ratio $\zeta$ of cable rigidity to girder stiffness, the bending moment of the stiffening girder decreases and that of the rigid cable rises. When $\xi$ varies from 0.1 to 5.0 , the maximum bending moment of the cable increases by $90 \%$. It should be noted that, in the case of the $2^{\text {nd }}$ type of bridge erection, the value of the bending moment of the cable is not subject to the ratio of short-term to permanent loading $\gamma$. This is explained by the fact that at the initial stage of installation under the action of permanent loading, the cable is considered to be completely flexible and the bending moment arises only from the effect of short-term loading, which is accepted as permanent.

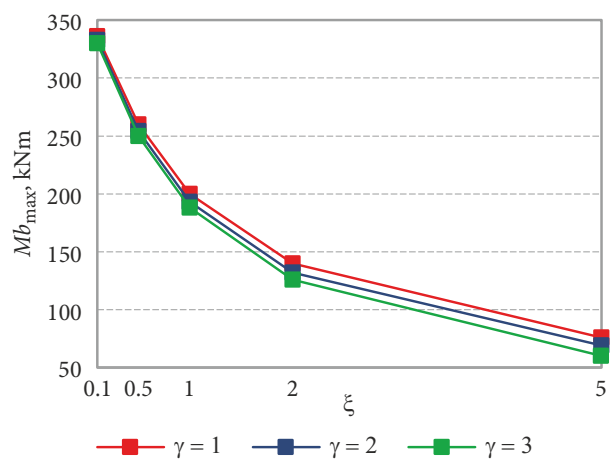

Figure 9 shows a chart of variations in the stress of the stiffening girder and cable subject to parameters $\zeta$ and $\gamma$. An increase in the ratio $\zeta$ of cable rigidity to girder stiffness from 0.1 to 5.0 results in a drop in girder strains down to $65 \%$. The total strains of the rigid cable decrease slightly. When $\zeta=5.0$, the total strains of the cable are only by $13 \%$ lower than those when $\zeta=0.1$. Thus, a reduction in strains under the effect of axial force increases strains under the action of the bending moment.

In the case of the $2^{\text {nd }}$ method for bridge erection, similarly to symmetrical loading, maximum bending moments and strains of both the rigid cable and stiffening girder are approximately by $50 \%$ lower than those discussed in the $1^{\text {st }}$ method.

Figure 10 shows a distorted scheme for the asymmetrical one-pylon suspension bridge under the effect of symmetrical loading.

Figure 8. Maximum moments of the stiffening girder (left) and cable (right) under the action of asymmetrical loading
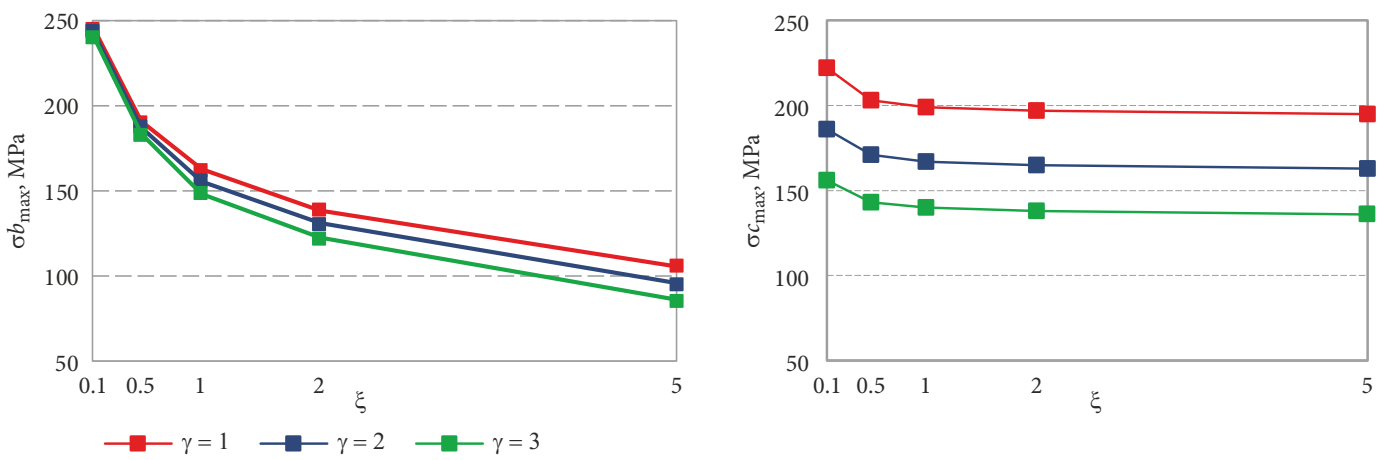

Figure 9. Maximum stresses of the stiffening girder (left) and rigid cable (right) under the action of asymmetrical loading

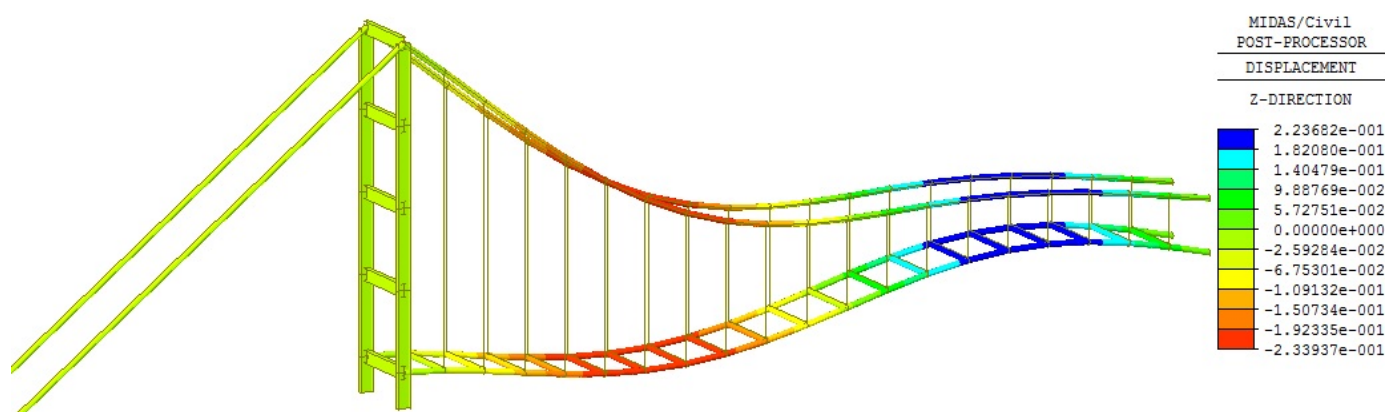

Figure 10. A deformed finite element model for the bridge under asymmetrical loading $(\xi=1.0, \gamma=1)$ 


\section{Conclusions}

The paper presents the numerical analysis of the asymmetrical one-pylon suspension bridge with rigid cables using the finite element method. The article analyses the models for the suspension bridge with the cables of different stiffness by comparing vertical displacements, bending moments and strains of the structural members of the bridge. Numerical analysis has been performed examining the load of the bridge under symmetrical and asymmetrical loading applying different methods for bridge erection.

An increase in the ratio of cable rigidity to grid stiffness up to $\zeta=5$ results in a decrease in vertical displacements down to $62 \%$. It has been determined that the structure the ratio of cable rigidity to grid stiffness of which varies from 0.5 to 2.0 is the most effective under both symmetri$\mathrm{cal}$ and asymmetrical loading. An increase in the ratio of rigidity/ stiffness up to 5.0 does not significantly affect the stress-strain state of the bridge. The maximum bending moments of the stiffening girder are reduced to $86 \%$.

The paper looks at the results of numerical analysis considering the $2^{\text {nd }}$ method for bridge erection when the cable, under the action of permanent symmetrical loading, is simulated as completely rigid. The findings of the analysis have demonstrated that, in the $2^{\text {nd }}$ method for bridge erection under both symmetrical and asymmetrical loading, the maximum bending moments and strains of the rigid cable and stiffening girder are by approximately $50 \%$ slighter than those observed in the $1^{\text {st }}$ method.

\section{References}

Arco, C. D., \& Aparicio, C. (2001). Preliminary static analysis of suspension bridges. Engineering Structures, 23(9), 1096-1103. https://doi.org/10.1016/S0141-0296(01)00009-8

Bennett, D. (1997). The architecture of bridge design. London: Thomas Telford Ltd. 200 p. https://doi.org/10.1680/taobd.25295

Capsoni, A., Ardito, R., \& Guerrieri, A. (2017). Stability of dynamic response of suspension bridges. Journal of Sound and Vibration, 393, 285-307. https://doi.org/10.1016/j.jsv.2017.01.009

Clemente, P., Nicolosi, G., \& Raithel, A. (2000). Preliminary design of very long-span suspension bridges. Engineering Structures, 22(12), 1699-1706. https://doi.org/10.1016/S0141-0296(99)00112-1

El Ouni, M. H., \& Kahla, N. B. (2012). Nonlinear dynamic analysis of a cable under first and second order parametric excitations. Journal of Civil Engineering and Management, 18(4), 557-567. https://doi.org/10.3846/13923730.2012.702994

Gimsing, N. J., \& Georgakis, Ch. T. (2012). Cable supported bridges: Concept and design ( $3^{\text {rd }}$ ed.). John Wiley \& Sons. 590 p.

Goremkins, V., Rocens, K., Serdjuks, D., \& Sliseris, J. (2013). Simplified method of determination of natural-vibration frequencies of prestressed suspension bridge. Procedia Engineering, 57, 343-352. https://doi.org/10.1016/j.proeng.2013.04.046

Grigorjeva, T., \& Juozapaitis, A. (2013). Revised engineering method for analysis of behavior of suspension bridge with rigid cables and some aspects of numerical modeling. Procedia Engineering, 57, 364-371.

https://doi.org/10.1016/j.proeng.2013.04.048
Grigorjeva, T., Juozapaitis, A., \& Kamaitis, Z. (2010a). Static analysis and simplified design of suspension bridges having various rigidity of cables. Journal of Civil Engineering and Management: International Research and Achievements, 16(3), 363-371. https://doi.org/10.3846/jcem.2010.41

Grigorjeva, T., Juozapaitis, A., \& Kamaitis, Z. 20(2010b). Influence of construction method on the behaviour of suspension bridges with main rigid cables. In Selected Papers of $10^{\text {th }}$ International Conference Modern Building Materials, Structures and Techniques (pp. 628-634 (+CD)). Vilnius: Technika.

Grigorjeva, T., Juozapaitis, A., Kamaitis, Z., \& Paeglitis, A. 20(2008). Finite element modelling for static behaviour analysis of suspension bridges with varying rigidity of main cables. The Baltic Journal of Road and Bridge Engineering, 3(3), 121-128. https://doi.org/10.3846/1822-427X.2008.3.121-128

Idnurm, J. (2006). Descrete analysis method for suspension bridges. The Baltic Journal of Road and Bridge Engineering, 1(2), 115-119.

Jennings, A. (1987). Deflection theory analysis of different cable profiles for suspension bridges. Engineering Structural, 9(2), 84-94. https://doi.org/10.1016/0141-0296(87)90002-2

Juozapaitis, A., Idnurm, S., Kaklauskas, G., Idnurm, J., \& Gribniak, V. (2010. Non-linear analysis of suspension bridges with flexible and rigid cables. Journal of Civil Engineering and Management, 16(1), 149-154.

https://doi.org/10.3846/jcem.2010.14

Juozapaitis, A., Kliukas, R., Sandovič, G., Lukoševičienè, O., \& Merkevičius, T. (2013). Analysis of modern three-span suspension bridges with stiff in bending cables. The Baltic Journal of Road and Bridge Engineering, 8(3), 205-211.

https://doi.org/10.3846/bjrbe.2013.26

Juozapaitis, A., \& Norkus, A. (2007). Shape determinating of a loaded cable via total displacements. Technological and Economic Development of Economy, 11(4), 283-291.

Kiisa, M., Idnurm, J., \& Idnurm, S. (2012). Descrete analysis of elastic cables. The Baltic Journal of Road and Bridge Engineering, 7(2), 98-103. https://doi.org/10.3846/bjrbe.2012.14

Kim, S. E., \& Thai, H.-T. (2010). Nonlinear inelastic dynamic analysis of suspension bridges. Engineering Structures, 32(12), 3845-3856. https://doi.org/10.1016/j.engstruct.2010.08.027

Kulbach, V. (2007). Cable structures. Design and analysis. Tallin: Estonian Academy Publisher. 224 p.

Ryall, M., Parke, G., \& Harding, J. (2000). The manual of bridges engineering. London: Tomas Telford Ltd. $1012 \mathrm{p}$.

Sousa, R., Souza, R. M., Figueiredo, F. P., \& Menezes, I. F. (2011). The influence of bending and shear stiffness and rotational inertia in vibration of cables: an analytical approach. Engineering Structures, 33(3), 689-695.

https://doi.org/10.1016/j.engstruct.2010.11.026

Strasky, J. (2005). Stress-ribbon and supported cable pedestrian bridges. London: Tomas Telford Ltd. 232 p.

https://doi.org/10.1680/sracspb.32828

Treyssede, F. (2010). Vibration analysis of horizontal self-weighted beams and cables with bending stiffness subject to thermal loads. Journal of Sound and Vibration, 329(9), 1536-1552. https://doi.org/10.1016/j.jsv.2009.11.018

Troyano, L. F. (2003). Bridge engineering: A global perspective. London: Tomas Telford Ltd. 775 p. https://doi.org/10.1680/beagp.32156

Wollmann, G. P. (2001). Preliminary analysis of suspension bridges. Journal of Bridge Engineering, 6(4), 227-233. https://doi.org/10.1061/(ASCE)1084-0702(2001)6:4(227) 